Bull. Chem. Soc. Ethiop. 2017, 31(3), 471-479.

ISSN 1011-3924

(C) 2017 Chemical Society of Ethiopia and The Authors

Printed in Ethiopia

DOI: http://dx.doi.org/10.4314/bcse.v31i3.11

\title{
ACTIVITY GUIDED ISOLATION OF CHEMICAL CONSTITUENTS FROM THE BIOLOGICALLY ACTIVE METHANOL EXTRACT OF EUPHORBIA SCHIMPERI C. PRESL
}

\author{
Sarfaraz Ahmed*, Mohammad Nur-e-Alam, Ramzi A. Mothana, Muhammad Yousaf and \\ Adnan J. Al-Rehaily \\ Department of Pharmacognosy, College of Pharmacy, King Saud University, P.O. Box 2457, \\ Riyadh 11451, Saudi Arabia
}

(Received May 7, 2017; Revised December 14, 2017; Accepted December 18, 2017)

\begin{abstract}
In this study we investigated the chemical constituents of bioactive methanol extract of Euphorbia schimperi C. Presl. For this the methanol extract was fractionated into $20,40,60,80 \% \mathrm{MeOH}$ in $\mathrm{CHCl}_{3}$, and $100 \% \mathrm{MeOH}$ fractions respectively by vacuum liquid chromatography. Excision wound surface of the animals were topically treated with these fractions at a dose of $100 \mathrm{mg} / \mathrm{kg}$ body weight for twenty days. Povidone-iodine ointment was used as a reference drug. Wound contraction measurement and period of epithelialization were used to assess the effect of fractions on wound repairing. The $100 \% \mathrm{MeOH}$ fraction treated animals achieved significant $(\mathrm{p}<0.001)$ value by showing $100 \%$ wound contraction and minimum period of epithelization $(17.75 \pm 0.47)$ on the $20^{\text {th }}$ day as compared to standard drug treated animals on the same day. The active $100 \%$ $\mathrm{MeOH}$ fraction was subjected to various chromatographic techniques led to the isolation of miquelianin (1), kaempferol 3-O-glucuronide (2) and quercitrin (3). Compounds (1-3) were isolated from this plant for the first time.
\end{abstract}

KEY WORDS: Euphorpia schimperi C. Presl, Wound healing, Chromatographic techniques, Chemical constituents

\section{INTRODUCTION}

Euphorbia is the largest genus in the plant family Euphorbiaceae with ca 2000 known species [1], and well recognized for chemical diversity of their isoprenoid constituents [2]. The latex of these plants contains many natural compounds, some of which are of therapeutic rank or of commercial usage. The latex usually defends these plants from browsing animals because of its unpleasant or poisonous nature [3]. The plants of the Euphorbia species are reported to have triterpene alcohols in their latex used as chemotaxonomic markers [4]. Additionally other constituents like cerebrosides, phloracetophenones, glycerols, sesquiterpenoids, steroids, and flavonoids are also reported [2].

Euphorpia schimperi C. Presl. (Euphorbiaceae) is available in Wadi Gama, Kingdom of Saudi Arabia [5]. Previously E. schimperi chloroform fraction had characterized cycloart-25-en$3 \beta, 24$-diol, cycloart-23-en-3 $\beta, 25$-diol, $\alpha$-amyrin, $\beta$-sitosterol- $\beta$-D- $O$-glucoside, scopoletin, luteolin and kaempferol [6]. It was also reported to possess anticancer, antimicrobial and antioxidant activities $[6,7]$.

Our previous work [8] on this plant demonstrated that methanol extract of the plant have significant wound healing activity. In continuation of our work we fractionated the methanol extract and tested for the wound healing activity. Furthermore the fraction that was showing highest wound healing activity was investigated for its chemical constituents that led to isolation of three compounds (1-3). Structure of these compounds was established on the basis of 1D, 2D NMR and mass spectral analysis and by comparison with reported values in literature. Compounds 1-3 were identified as miquelianin, kaempferol 3-O-glucuronide [9] and quercitrin [10], respectively (Figure 1).

*Corresponding author. E-mail: sarahmed@ksu.edu.sa

This work is licensed under the Creative Commons Attribution 4.0 International License 


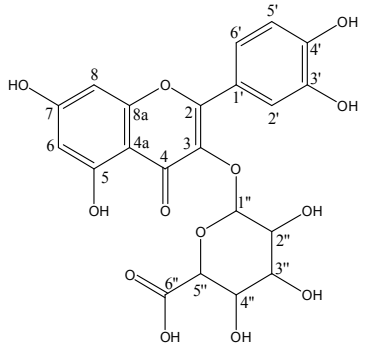

1

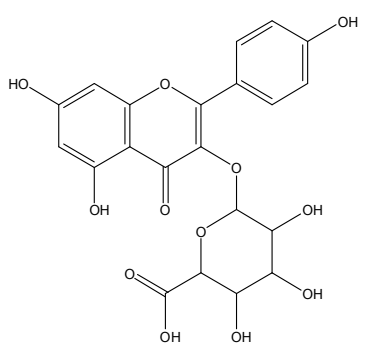

2

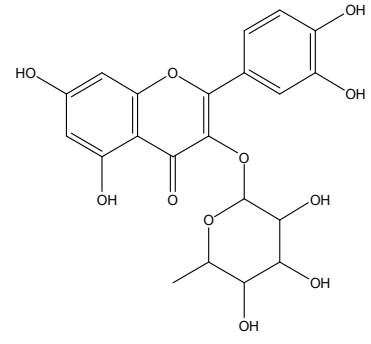

3

Figure 1. Structure of compounds 1-3.

\section{EXPERIMENTAL}

General

The ${ }^{1} \mathrm{H}$ and ${ }^{13} \mathrm{C}$ NMR spectra were measured on a Bruker Avance spectrometer, operating at 700 $\mathrm{MHz}$ for ${ }^{1} \mathrm{H}$ and $175 \mathrm{MHz}$ for ${ }^{13} \mathrm{C}$. The ESI MS were obtained on an Agilent Mass spectrometer series 1100 SL. For analytical purposes TLC plates coated with $\mathrm{UV}_{254}$ fluorescence indicator (Merck) were used. Compounds were visualized under UV radiation in CAMAG UV cabinet dual wavelength, $254 / 366 \mathrm{~nm}$ and also by spraying with $p$-anisaldehyde $/ \mathrm{H}_{2} \mathrm{SO}_{4}$ reagent to visualize spots. Silica gel $60\left(230-400 \mu \mathrm{m}\right.$; Merck, Darmstadt) and Sephadex ${ }^{\circledR}$ LH-20, GE Healthcare, was utilized for column chromatography (CC). HPLC was performed on a Shimadzu system (Kyoto, Japan), consisting of two LC-6AD semi-preparative solvent delivery pumps, bus module CBM-20A, a multi wavelength photo-diode array detector (SPD-M20A), columns shim-pack PREP-ODS (H) Kit (A) $250 \mathrm{~mm} \times 4.6 \mathrm{~mm}$ I.D. with $5 \mu \mathrm{m}$ particles (B) 250 $\mathrm{mm} \times 20 \mathrm{~mm}$ I.D. $5 \mu \mathrm{m}$.

\section{Plant material}

The plant was collected from Wadi Gama in February 2014, Kingdom of Saudi Arabia (KSA) and identified by taxonomist, Dr. M. Yousuf. A voucher specimen (16322) was deposited at the Herbarium of the College of Pharmacy, King Saud University, Riyadh, KSA.

\section{Extraction and isolation}

A $1.24 \mathrm{~kg}$ dried and ground material of plant was extracted with ethyl acetate followed by methanol at room temperature for $72 \mathrm{~h}(3 \times 24 \mathrm{~h})$. The extracts were filtered through Whatman No.1 filter paper and solvent was evaporated to dryness at $40{ }^{\circ} \mathrm{C}$ in vacuo using Buchi Rotavapor (Model R-215) yielded syrupy mass of ethyl acetate and methanol extracts. The methanol extract showed $100 \%$ wound healing activity. Out of $90 \mathrm{~g} \mathrm{MeOH}$ extract, $69 \mathrm{~g}$ was subjected to vacuum liquid chromatography and eluted in sequence with $\mathrm{CHCl}_{3}$ and $\mathrm{MeOH}$ mixture gave five fractions and all fractions were tested for wound healing activity. The fraction obtained with $100 \% \mathrm{MeOH}$ was found to possess significant activity and was considered for chemical investigation which led to the isolation of three compounds. The detailed isolation scheme is depicted in Figure 2. 


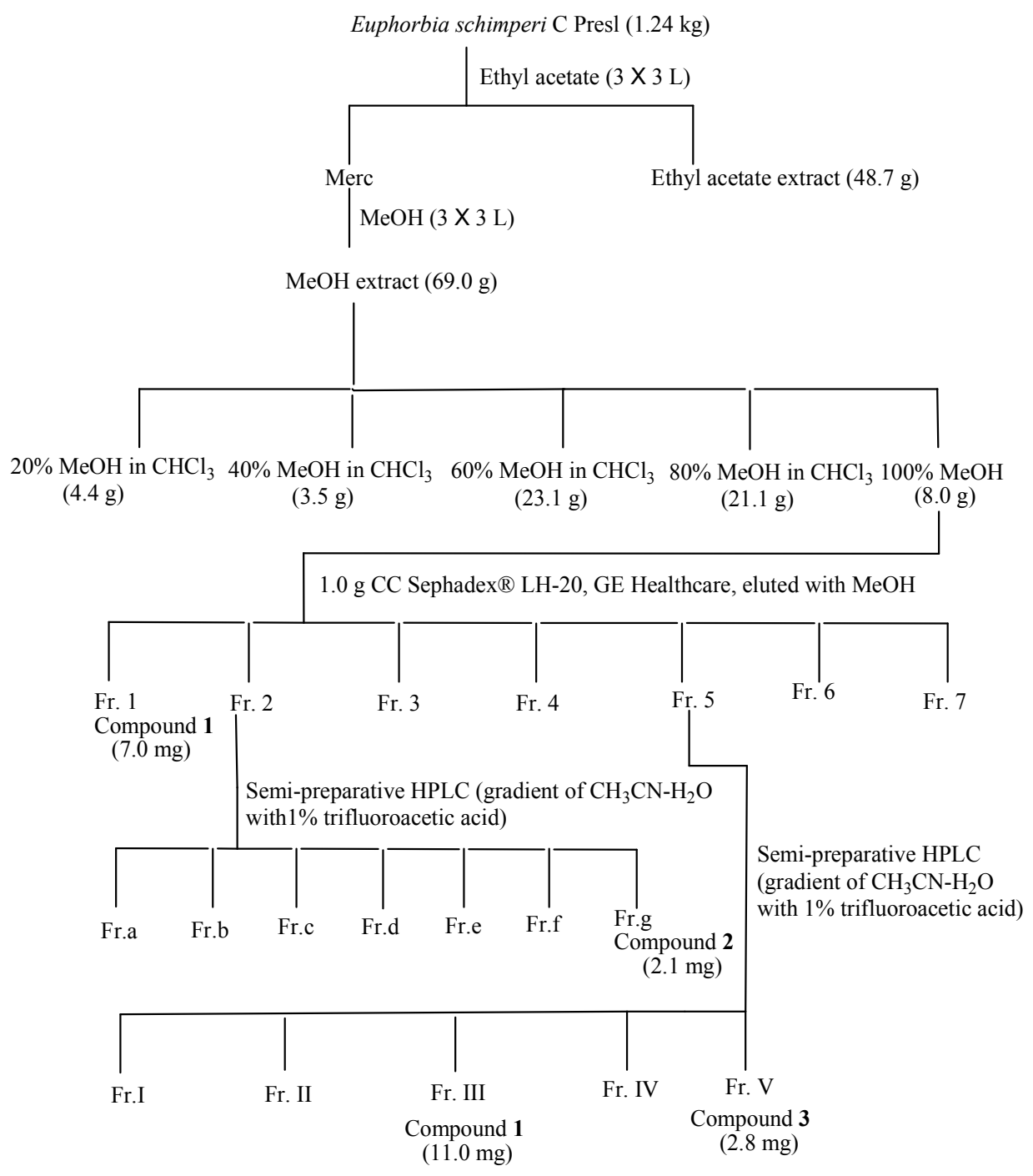

Figure 2. Isolation scheme.

Wound healing studies

Wistar albino rats of either sex used in these experiments were obtained from experimental animal house, College of Pharmacy, KSU, Riyadh. Animals used were of the same age group, weighing roughly about $180-200 \mathrm{~g}$ b.w. The experimental animals were accommodated under standard laboratory conditions, temperature $\left(22 \pm 2{ }^{\circ} \mathrm{C}\right)$, humidity $(55 \%)$ and $12 / 12$ hours lightdark environment. The animals were maintained on standard diet Purina chow and free access to drinking water ad libitum. The experimental protocol for animal work was approved (No. EACP7315) by Ethics Committee for Animal Experimentation, College of Pharmacy, KSU, 
Riyadh, Saudi Arabia. All the experimental procedure exercised was according to the National Institutes of Health Guide for the Care and Use of Laboratory Animals, Institute for laboratory animals (NIH publication $8^{\text {th }}$ edition, 2011).

The rats were anaesthetized with diethyl ether prior to and throughout the infliction of experimental wounds. The anesthetized rats inflicted with excision wounds as designed by Morton and Malone [11] and in our previous paper [8]. In short, the dorsal skin fur of the animals was shaved with an electric shaver, and the outline of the wound to be created was demarcated on the back of the animals with methylene blue using a circular stainless steel stencil. A full skin thickness of the excision wound of circular area of $254 \mathrm{~mm}^{2}$ and $2 \mathrm{~mm}$ depth was formed along the markings with a surgical blade and pointed scissor.

The wounded animals were divided into seven groups of four animals in each group. Group 1 animals were left untreated (control group). Group 2 served as reference standard and treated topically with povidone-iodine $(5 \% \mathrm{w} / \mathrm{w})$, group 3 to 7 were treated topically with $20 \% \mathrm{MeOH}$ in $\mathrm{CHCl}_{3}$ fraction, $40 \% \mathrm{MeOH}$ in $\mathrm{CHCl}_{3}$ fraction, $60 \% \mathrm{MeOH}$ in $\mathrm{CHCl}_{3}$ fraction, $80 \% \mathrm{MeOH}$ in $\mathrm{CHCl}_{3}$ fraction and $100 \% \mathrm{MeOH}$ fraction, respectively, at a dose of $100 \mathrm{mg} / \mathrm{kg} \mathrm{b.w}$. The fractions and standard drugs were applied topically once a day, starting from the day of wound creation, till complete epithelialization. The animals were housed individually in cages. The wounds were traced on $\mathrm{mm}^{2}$ graph paper on the day of $4,8,12,16$ and 20 post wounding days. The percentage of wound closure ( $\%$ contraction), and period of epithelialization were calculated.

\section{Statistical analysis}

Values are given as arithmetic means \pm standard error of the mean (S.E.M.). Data was statistically analyzed by using one-way analysis of variance (ANOVA) followed by Student's t-test. The data were considered significant at $\mathrm{p}<0.001$.

\section{RESULTS}

\section{Wound healing}

The wound healing efficacy of the methanol extract fractions $\left(20 \% \mathrm{MeOH}\right.$ in $\mathrm{CHCl}_{3}, 40 \%$ $\mathrm{MeOH}$ in $\mathrm{CHCl}_{3}, 60 \% \mathrm{MeOH}$ in $\mathrm{CHCl}_{3}, 80 \% \mathrm{MeOH}$ in $\mathrm{CHCl}_{3}$ and $100 \% \mathrm{MeOH}$ ) used in the study is summarized in Table 1 and 2 and Figure 3. The parameters used in this excision wound model study were percentage wound closure and mean epithelialization time and these two parameters were measured on $0,4,8,12,16$, and 20 days. During the course of study it was found that the wound contracting ability of $20 \% \mathrm{MeOH}$ in $\mathrm{CHCl}_{3}$ and $100 \% \mathrm{MeOH}$ fractions treated group animals showed noticeable wound contraction and reduction in the epithelialization period from the fourth day onwards, when compared with that of standard drug treated group animals. On the fourth day the $20 \% \mathrm{MeOH}$ in $\mathrm{CHCl}_{3}$ fraction treated animals showed $14.66 \%$ of wound closure which was very near to that of standard drug treated animals $15.24 \%$ while $100 \% \mathrm{MeOH}$ fraction showed higher $18.88 \%$ of wound closure compared to that of standard drug treated animals. Conversely on the $8^{\text {th }}$ day the wound closure percentage was found $39.23 \%$ and $39.39 \%$ in $20 \% \mathrm{MeOH}$ in $\mathrm{CHCl}_{3}$ and $100 \% \mathrm{MeOH}$ treated animals as compared to standard drug treated group animals $(40.48 \%)$. While on $12^{\text {th }}$ day of study $20 \%$ $\mathrm{MeOH}$ in $\mathrm{CHCl}_{3}$ fraction treated animals showing $70.31 \%$ of wound closure which is slightly higher than $100 \% \mathrm{MeOH}$ fraction treated animals (69.18\%) as well as standard drug treated animal $(68.51 \%)$. On the $16^{\text {th }}$ day, $96.14 \%$ wound shrinkage was found in $100 \% \mathrm{MeOH}$ fraction treated animals compared to that of standard drug treated animals $(96.39 \%)$ while on the same day $20 \% \mathrm{MeOH}$ in $\mathrm{CHCl}_{3}$ fraction treated animals showing $95.66 \%$ wound closure. On the $20^{\text {th }}$ day of experiment only $100 \% \mathrm{MeOH}$ fraction treated animals achieved significant value $(\mathrm{p}<$ 
0.001 ) and showed $100 \%$ wound closure and minimum period of epithelialization which was the same as that of standard drug treated animals.

The percentage of wound closure of $20 \% \mathrm{MeOH}$ in $\mathrm{CHCl}_{3}$ fraction treated animals increased gradually from $4^{\text {th }}$ to $20^{\text {th }}$ day and reached to $99.43 \%$. This may be attributed due to the presence of other chemical constituents which are not present in $100 \% \mathrm{MeOH}$ fraction because the TLC profile of $20 \% \mathrm{MeOH}$ in $\mathrm{CHCl}_{3}$ fraction was totally different from $100 \% \mathrm{MeOH}$ fraction. On the other hand, the animals treated with $40 \% \mathrm{MeOH}$ in $\mathrm{CHCl}_{3}, 60 \% \mathrm{MeOH}$ in $\mathrm{CHCl}_{3}$ and $80 \%$ $\mathrm{MeOH}$ in $\mathrm{CHCl}_{3}$ fractions were not showing considerable activity. Since the wound healing effects of $100 \% \mathrm{MeOH}$ fraction was found highest (100\% wound contraction) encouraged us to investigate this fraction for its chemical constituents.

Table 1. Effect of extracts on excision wound healing potential in rats (wound area $\mathrm{mm}^{2}$ )

\begin{tabular}{|c|c|c|c|c|c|c|c|}
\hline Groups & Dose $\mathrm{mg} / \mathrm{kg}$ & \multicolumn{6}{|c|}{ Wound Contraction (\%) } \\
\hline & & 0 Days & $4^{\text {th }}$ & $8^{\text {th }}$ & $12^{\text {th }}$ & $16^{\text {th }}$ & $20^{\text {th }}$ \\
\hline 1 & & 00 & 3.16 & 17.12 & 42.96 & 71.22 & 80.96 \\
\hline 2 & Topical & 00 & 15.24 & 40.48 & 68.51 & 96.39 & 100 \\
\hline 3 & 100 & 00 & 14.66 & 39.23 & 70.31 & 95.66 & 99.43 \\
\hline 4 & 100 & 00 & 8.17 & 15.60 & 55.67 & 76.51 & 91.70 \\
\hline 5 & 100 & 00 & 5.08 & 16.99 & 55.26 & 80.62 & 91.64 \\
\hline 6 & 100 & 00 & 9.02 & 22.42 & 61.96 & 87.93 & 98.27 \\
\hline 7 & 100 & 00 & 18.88 & 39.39 & 69.18 & 96.14 & 100 \\
\hline
\end{tabular}

Data are mean of 4 male in each group $\pm \mathrm{SD} ; * \mathrm{p}<0.05, * * \mathrm{p}<0.01, * * * \mathrm{p}<0.001$ student's t-test. Group 1 Untreated animals. Group 2 Animals treated with povidone-iodine. Group 3 Animals treated with $20 \% \mathrm{MeOH}$ in $\mathrm{CHCl}_{3}$ fraction. Group 4 Animals treated with $40 \% \mathrm{MeOH}$ in $\mathrm{CHCl}_{3}$ fraction. Group 5 Animals treated with $60 \%$ $\mathrm{MeOH}$ in $\mathrm{CHCl}_{3}$ fraction. Group 6 Animals treated with $80 \% \mathrm{MeOH}$ in $\mathrm{CHCl}_{3}$ fraction. Group 7 Animals treated with $100 \% \mathrm{MeOH}$ fraction.

Table 2. Effect of extracts on percent wound contraction in excision wound in rat.

\begin{tabular}{|c|c|c|c|c|c|c|c|c|}
\hline Groups & $\begin{array}{l}\text { Dose } \\
\mathrm{mg} / \mathrm{kg}\end{array}$ & $\begin{array}{c}0 \\
\text { Days }\end{array}$ & $\begin{array}{l}4^{\text {th }} \\
\text { Day }\end{array}$ & $\begin{array}{l}8^{\text {th }} \\
\text { Day }\end{array}$ & $\begin{array}{l}12^{\text {th }} \\
\text { Day }\end{array}$ & $\begin{array}{l}16^{\text {th }} \\
\text { Day }\end{array}$ & $\begin{array}{l}20^{\text {th }} \\
\text { Day }\end{array}$ & $\begin{array}{l}\text { Period of } \\
\text { epithelization } \\
\text { (days) }\end{array}$ \\
\hline 1 & & $\begin{array}{c}333.25 \\
\pm 2.97\end{array}$ & $\begin{array}{l}322.80 \\
\pm 2.44^{*}\end{array}$ & $\begin{array}{c}276.27 \\
\pm 5.47 * * *\end{array}$ & $\begin{array}{c}190.12 \\
\pm 8.36^{* * *}\end{array}$ & \begin{tabular}{|c|}
95.92 \\
$\pm 7.24 * * *$ \\
\end{tabular} & \begin{tabular}{|c|}
63.45 \\
$\pm 6.84 * * *$ \\
\end{tabular} & $24.50 \pm 0.64$ \\
\hline 2 & Topical & $\begin{array}{c}335.25 \\
\pm 1.96\end{array}$ & $\begin{array}{c}284.05 \\
\pm 8.37 * * * \\
\end{array}$ & $\begin{array}{c}199.45 \\
\pm 6.31 * * * \\
\end{array}$ & $\begin{array}{c}105.42 \\
\pm 3.30 * * *\end{array}$ & $\begin{array}{c}12.07 \\
\pm 0.93 * * * \\
\end{array}$ & - & $17.50 \pm 0.28 * * *$ \\
\hline 3 & 100 & $\begin{array}{c}334.62 \\
\pm 3.35\end{array}$ & $\begin{array}{c}285.55 \\
\pm 7.42 * * * \\
\end{array}$ & $\begin{array}{c}203.32 \\
\pm 1.23 * * *\end{array}$ & $\begin{array}{c}99.35 \\
\pm 4.93 * * *\end{array}$ & $\begin{array}{c}14.50 \\
\pm 1.79 * * * \\
\end{array}$ & $\begin{array}{c}1.87 \\
\pm 0.67 * * * \\
\end{array}$ & $21.00 \pm 0.40 * *$ \\
\hline 4 & 100 & $\begin{array}{c}329.45 \\
\pm 2.69\end{array}$ & $\begin{array}{c}302.52 \\
\pm 5.34 * *\end{array}$ & $\begin{array}{c}278.02 \\
\pm 4.71 * * *\end{array}$ & $\begin{array}{c}146.02 \\
\pm 6.24 * * *\end{array}$ & $\begin{array}{c}77.37 \\
\pm 6.85^{* * *}\end{array}$ & $\begin{array}{c}27.32 \\
\pm 1.99 * * *\end{array}$ & $22.50 \pm 0.64$ \\
\hline 5 & 100 & $\begin{array}{c}327.40 \\
\pm 1.86\end{array}$ & $\begin{array}{l}310.75 \\
\pm 4.60^{*}\end{array}$ & $\begin{array}{c}271.75 \\
\pm 3.47 * * *\end{array}$ & $\begin{array}{c}146.45 \\
\pm 5.15^{* * *}\end{array}$ & $\begin{array}{c}63.42 \\
\pm 4.90 * * *\end{array}$ & $\begin{array}{c}27.35 \\
\pm 1.97 * * *\end{array}$ & $21.25 \pm 0.8^{* *}$ \\
\hline 6 & 100 & $\begin{array}{c}327.47 \\
\pm 0.83\end{array}$ & $\begin{array}{c}297.92 \\
\pm 5.88^{* *}\end{array}$ & $\begin{array}{c}254.02 \\
\pm 4.38 * * *\end{array}$ & $\begin{array}{c}124.55 \\
\pm 3.58^{* * *}\end{array}$ & $\begin{array}{c}39.50 \\
\pm 1.38^{* * *}\end{array}$ & $\begin{array}{c}5.655 \\
\pm 1.07 * * *\end{array}$ & $21.50 \pm 0.28^{* *}$ \\
\hline 7 & 100 & $\begin{array}{c}336.30 \\
\pm 2.23\end{array}$ & $\begin{array}{c}272.80 \\
\pm 3.23 * * *\end{array}$ & $\begin{array}{c}203.80 \\
\pm 1.16 * * *\end{array}$ & $\begin{array}{c}103.62 \\
\pm 2.93 * * *\end{array}$ & $\begin{array}{c}12.95 \\
\pm 0.82 * * *\end{array}$ & - & $17.75 \pm 0.47 * * *$ \\
\hline
\end{tabular}

Data are mean of 4 male in each group $\pm \mathrm{SD} ;{ }^{*} \mathrm{p}<0.05,{ }^{* *} \mathrm{p}<0.01,{ }^{* * *} \mathrm{p}<0.001$ student's t-test. Group 1 Untreated animals. Group 2 Animals treated with povidone-iodine. Group 3 Animals treated with $20 \% \mathrm{MeOH}$ in $\mathrm{CHCl}_{3}$ fraction. Group 4 Animals treated with $40 \% \mathrm{MeOH}$ in $\mathrm{CHCl}_{3}$ fraction. Group 5 Animals treated with $60 \%$ $\mathrm{MeOH}$ in $\mathrm{CHCl}_{3}$ fraction. Group 6 Animals treated with $80 \% \mathrm{MeOH}$ in $\mathrm{CHCl}_{3}$ fraction. Group 7 Animals treated with $100 \% \mathrm{MeOH}$ fraction. 


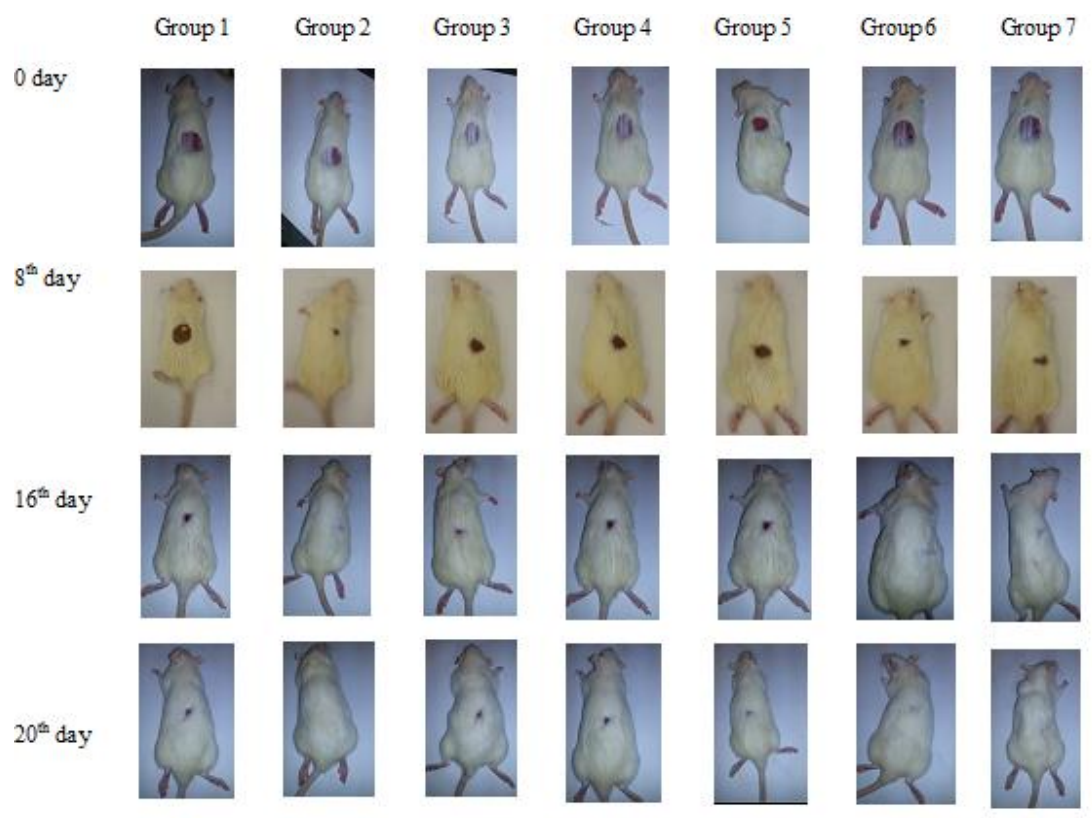

Figure 3. Effect of topical application of methanol extract fractions on $8^{\text {th }}, 16^{\text {th }}$ and $20^{\text {th }}$ day on wound healing. Group 1 Untreated animals, Group 2 Animals treated with povidoneiodine, Group 3 Animals treated with $20 \% \mathrm{MeOH}$ in $\mathrm{CHCl}_{3}$ fraction, Group 4 Animals treated with $40 \% \mathrm{MeOH}$ in $\mathrm{CHCl}_{3}$ fraction, Group 5 Animals treated with $60 \% \mathrm{MeOH}$ in $\mathrm{CHCl}_{3}$ fraction, Group 6 Animals treated with $80 \% \mathrm{MeOH}$ in $\mathrm{CHCl}_{3}$ fraction, Group 7 Animals treated with $100 \% \mathrm{MeOH}$ fraction.

\section{DISCUSSSION}

The process of wound healing involved tissues restoration and re-establishment of damaged skin and tissues [12]. It includes an organized movement of actions i.e. inflammation, angiogenesis, proliferation and synthesis of collagen for final healing [13]. The signs associated with wounds are discharge of blood, redness and painful swelling around the wound, puss and water discharge accumulation beneath the skin or drainage and obscene odor from the wounds [14]. Although, wound healing is a natural process and have the capacity to its own healing to restore the integrity. To avoid severe injury to the body; rapid wound healing is required [15].

The results of the present study demonstrated excellent rate of wound healing through topical application of $100 \% \mathrm{MeOH}$ fraction which showed $100 \%$ wound closure and healing on experimentally induced excision wounds, comparable to that of standard drug treated groups and control animals.

The role of antioxidant compounds from plant extractives in wound healing has been reported extensively [16]. Flavonoids, the main constituents present in many plant extracts, act as powerful free radical scavengers [17]. Many studies demonstrated positive correlation between antioxidant activity and phenolic content of plant extracts [18]. The free radical scavenging activity of plant flavonoids help in healing of wounds [19]. The antioxidant defense mechanism of the body comprises enzymes like superoxide dismutase, catalase, and glutatione 
peroxidase conversely also have non enzymatic parts such as glutathione, ascorbic acid, and $\alpha$ tocopherol. The enhancement in production of reactive oxygen species during injury results in consumption and reduction of the endogenous scavenging compounds. Flavonoids may have an additive effect to the endogenous scavenging compounds [20].

Since miquelianin possessing the structure of quercetin 3-O-glucuronide has been reported to have anti-depressant activity [21], anti-stress activity [22], cytotoxic and anti-oxidant activity [23], anti-psoriatic activity [24], anti-inflammatory and anti-viral activity [25]. Another isolated compound, kaempferol 3- $O$-glucuronide also possessed cytotoxic and anti-oxidant activity [23]. Quercitrin, a well-recognized flavonoid glycoside has anti-diarrheic activity [26], sedative activity [27], anti-inflammatory effect [28-30], anti-fungal activity [31] and anti-oxidant activity [32].

In view of the pharmacological properties related to flavonoids in general and particularly with isolated compound(s), possibly, the wound healing property of E. schimperi methanol extract may be attributed due the presence of compounds (miquelianin, kaempferol 3-Oglucuronide and quercitrin) which may be either due to their individual or additive effect that increase the wound healing process.

\section{CONCLUSION}

This study demonstrated significant wound healing activity of $100 \% \mathrm{MeOH}$ fraction by increasing rate of epithelization and wound contraction. The chemical constituents of this methanol fraction have been identified. The methanol fraction and the isolated compounds therefore may be a lead in the drug discovery of new wound healing agents.

\section{ACKNOWLEDGMENTS}

The authors extended their appreciation to Deanship of Scientific Research at King Saud University, for funding the work through the research group project No. (RGP-073). The technical support of Mr. Malik Sawood Ahmed is thankfully acknowledged.

\section{REFERENCES}

1. Jassbi, A.R. Chemistry and biological activity of secondary metabolites in Euphorbia from Iran. Phytochemistry 2006, 67, 1977-1984.

2. Shi, Q.W.; Su, X.H.; Kiyota, H. Chemical and pharmacological research of the plants in genus Euphorbia. Chem. Rev. 2008, 108, 4295-4327.

3. AL-Sultan, S.I.; Hussein, Y.A. Acute toxicity of Euphorbia heliscopia in Rats. Pak. J. Nut. 2006, 5, 135-140.

4. Giner, J.L.; Schroeder, T.N. Polygonifoliol, a new tirucallane triterpene from the latex of the seaside sandmat Euphorbia polygonifolia. Chem. Biodiver. 2015, 12, 1126-1129.

5. Chaudhary, S.A. Flora of Kingdom of Saudi Arabia Illustrated. Ministry of Agriculture and Water, 2nd ed., National Herbarium, National Agriculture and Water Research Center: Riyadh; 2001; p 331.

6. Abdel-Monem, A.R.; Abdel-Sattar, E.; Harraz, F.M.; Petereit, F. Chemical investigation of Euphorbia schimperi C. Presl. Rec. Nat. Prod. 2008, 2, 39-45.

7. Mothana, R.A.; Gruenert, R.; Bednarski, P.J.; Lindequist, U. Evaluation of the in vitro anticancer, antimicrobial and antioxidant activities of some Yemeni plants used in folk medicine. Die Pharmazie 2009, 64, 260-268.

8. Ahmed, S.; Yousaf, M.; Mothana, R.A.; Al-Rehaily, A.J. Studies on wound healing activity of some Euphorbia species on experimental rats. Afr. J. Tradit. Complement. Altern. Med. 2016, 13, 45-52. 
9. Nugroho, A.; Song, B.M.; Lee, K.T.; Park, H.J. Quantification of antidepressant miquelianin in mature and immature fruits of Korean Rubus species. Nat. Prod. Sci. 2014, 20, 258-261.

10. Ma, X.; Tian, W.; Wu, L.; Cao, X.; Ito, Y. Isolation of quercetin-3- $O$-L-rhamnoside from Acer truncatum Bunge by high-speed counter-current chromatography. J. Chromatogr. A. 2005, 1070, 211-214.

11. Morton, J.J.; Malone, M.H. Evaluation of vulneray activity by an open wound procedure in rats. Arch.Int. Pharmacodyn. Ther. 1972, 196, 117-126.

12. Dash, G.K.; Murthy, P.N. Studies on wound healing activity of Heliotropium indicum Linn leaves on rats. ISRN Pharmacol. 2011, Article ID 847980.

13. Hemamalini, K.; Ramu, A.; Mallu, G.; Srividya, V.V.; Sravani, V.; Deepak, P.; Reddy, U.V. Evaluation of wound healing activity of different crude extracts of Anogeissus acuminata and Gymnosporia emerginata. Rasayan J. Chem. 2011, 4, 466-471.

14. Phillips, G.D., Whitehead, R.A.; Kinghton, D.R. Initiation and pattern of angiogenesis in wound healing in the rats. Am. J. Anat. 1991, 192, 257-262.

15. Thring, T.S.; Hili, P.; Naughton, D.P. Anti-collagenase, anti-elastase and anti-oxidant activities of extracts from 21 plants. BMC Complem. Altern. Med. 2009, 9, 17-27.

16. Suriyamoorthy, S.; Subramaniam, K.; Durai, S.J.R.; Wahaab, F.; Chitraselvi, R.P.E. Evaluation of wound healing activity of Acacia caesia in rats. Wound Medicine 2014, 7, 17.

17. Yenesew, A.; Twinomuhwezi, H.; Kiremire, B.T.; Mbugua, M.N.; Gitu, P.M.; Heydenreich, M.; Peter, M.G. 8-Methoxyneorautenol and radical scavenging flavonoids from Erythrina abyssinica. Bull. Chem. Soc. Ethiop. 2009, 23, 205-210.

18. Elzaawely, A.A.; Tawata, S. Antioxidant activity of phenolic rich fraction obtained from Convolvulus arvensis L., leaves grown in Egypt. Asian J. Crop. Sci. 2012, 4, 32-40.

19. Havsteen, B.H. The biochemistry and medical significance of the flavonoids. Pharmacol. Ther. 2002, 96, 67-202.

20. Nijveldt, R.J.; van Nood, E.; van Hoorn, D.E.; Boelens, P.G.; van Norren, K.; van Leeuwen, P.A. Flavonoids: A review of probable mechanisms of action and potential applications. Am. J. Clin. Nutr. 2001, 74, 418-425.

21. Butterweck, V.; Jürgenliemk, G.; Nahrstedt, A.; Winterhoff, H. Flavonoids from Hypericum perforatum show antidepressant activity in the forced swimming test. Planta Med. 2000, 66, 3-6.

22. Trofimiuk, E.; Braszko, J.J. Alleviation by Hypericum perforatum of the stress-induced impairment of spatial working memory in rats. Naunyn Schmiedebergs Arch. Pharmacol. 2008, 37, 463-471.

23. Badria, F.A.; Ameen, M.; Akl, M.R. Evaluation of cytotoxic compounds from Calligonum comosum L. Growing in Egypt. Z. Naturforsch 2007, 62c, 656-660.

24. Vijayalakshmi, A.; Geetha, M. Anti-psoriatic activity of flavonoids from Cassia tora leaves using the rat ultraviolet B ray photo dermatitis model. Rev. Bras. Farma. 2014, 24, 322-329.

25. Fan, D.; Zhou, X.; Zhao, C.; Chen, H.; Zhao, Y.; Gong, X. Antiinflammatory, antiviral and quantitative study of quercetin-3-O- $\beta$-D-glucuronide in Polygonum perfoliatum L. Fitoterapia. 2011, 82, 805-810.

26. Galvez, J.; Crespo, M.E.; Jimenez, J.; Suarez, A.; Zarzuelom, A. Antidiarrhoeic activity of quercitrin in mice and rats. J. Pharm. Pharmacol. 1993, 45, 157-159.

27. Kang, T.H.; Jeong, S.J.; Kim, N.Y.; Higuchi, R.; Kim, Y.C. Sedative activity of two flavonol glycosides isolated from the flowers of Albizzia julibrissin Durazz. $J$. Ethnopharmacol. 2000, 71, 321-323.

28. Sanchez de Medina, F.; Galvez, J.; Romero, J.A.; Zarzuelo, A. Effect of quercitrin on acute and chronic experimental colitis in the rat. J. Pharmacol. Exp. Ther. 1996, 278, 771-779. 
29. Manga, H.M.; Brkic, D.; Marie, D.E.P.; Quetin-Leclercq, J. In vivo antiinflammatory activity of Alchornea cordifolia (Schumach. \& Thonn.) Mull. Arg. (Euphorbiaceae). J. Ethnopharmacol. 2004, 92, 209-214.

30. Sanchez de Medina, F.; Vera, B.; Galvez, J.; Zarzuelo, A. Effect of quercitrin on the early stages of hapten induced colonic inflammation in the rat. Life Sci. 2002, 70, 3097-3108.

31. Lu, Y.H.; Zhang, Z.; Shi, G.X.; Meng, J.C.; Tan, R.X. A new antifungal flavonol glycoside from Hypericum perforatum. Act. Bot. Sin. 2002, 44, 743-745.

32. Babujanarthanam, R.; Kavitha, P.; Mahadeva Rao, U.S.; Pandian, M.R. Quercitrin a bioflavonoid improves the antioxidant status in streptozotocin: Induced diabetic rat tissues. Mol. Cell. Biochem. 2011, 358, 121-129. 